\title{
The Effect Of Green Marketing Of Plastic Bag Ban Policy In Modern Retail Stores On Consumer Green Behavior In Bogor City
}

\author{
Harfin Nurulhaq ${ }^{1, *}$, Kismartini $^{1}$ \\ ${ }^{1}$ Master Program of Environmental Science, School of Postgraduate Studies, Diponegoro University, Semarang - Indonesia
}

\begin{abstract}
The plastic bag ban policy in every modern retail store is a policy made by the Bogor City Government to reduce plastic waste and encourage an environmentally friendly lifestyle. This policy is stipulated in the Bogor Mayoral Regulation Number 61 of 2018. The policy marketing can be carried out by green marketing process. This study aimed to identify the public response regarding the use of their shopping bags, to identify consumer perception of the plastic bag ban policy, and to identify the effect of green marketing of plastic bag ban policy on green behavior in Bogor City. Primary data was obtained through questionnaire and secondary data were obtained from the archive of Bogor Industry and Trade Department. Data were analyzed using descriptive analysis and structural equation models. The results indicated that after the policy was implemented, more consumers were willing to reduce the use of plastic bags and bring their shopping bags. The green marketing process which had a significant effect on green behavior was to know your customer, empowering the customer and reassure the buyer.
\end{abstract}

Keywords: Greean Marketing; Plastic Policy; Green Behavior.

\section{Introduction}

Environmental and ecosystem damage can be caused by various factors, including the accumulation of residual waste or industrial and household waste. Natural conditions have changed significantly over the past 30 to 40 years since the introduction of synthetic materials such as plastics. Indonesia is the second largest country contributing to plastic waste pollution in the ocean after China [1].

Urban or metropolitan areas are a manifestation of the rapid natural development of a globalization process. This development leads to a significant increase in population, with different and specific characteristics and problems. Therefore, an urban area requires its management in solving the problems.

One crucial problem in urban areas is an urban waste. To this day, the urban waste problem has never been resolved. The high population density creates high community consumption, while the land to accommodate the waste generated from consumption is limited. Urban waste management remains incomplete, this does not only have a negative impact on the aesthetics of the urban environment, but also causes other problems, such as flooding, environmental pollution, decreasing the degree of public health, and also social problems.

Waste can be interpreted as a consequence of the activities of human life. Eveary year, it can be ascertained that waste volume will always increase along with the increasing pattern of community consumerism. The Ministry of Environment and Forestry (KLHK) in 2012 stated that the average population in Indonesia generated around 2.5 liters of waste per day or 625 million liters of the total population. This condition will continue to grow in accordance with its environmental conditions. According to Indonesia's Waste Statistics, the total amount of waste in Indonesia reached 38.5 million tons per year with the largest amount of waste in Java 2012 (21.2 million tons per year). The waste included organic and inorganic waste. The increasing waste generation in Indonesia has reached 175,000 tons/day, equivalent to 64 million tons/year. The biggest challenge for waste management is handling the non-environmentally friendly plastic waste. The efforts to reduce the generation of plastic waste both in waste sources and in landfills are the challenge for future waste management for the Government of Indonesia.

Waste reduction activity aims at all parts of society, including government, business entities and the wider community, carry out the activities of limiting waste generation, recycling and reusing waste or better known as Reduce, Reuse and Recycle (3R) through smart, efficient and programmed efforts. Nevertheless, this $3 R$ activity faces major obstacles, namely the low public awareness to sort out waste, and a large amount of inorganic waste which cannot be decomposed by the

\footnotetext{
* Corresponding author: harfinnuurulhag@gmail.com
} 
biological process, such as plastic. Indonesia ranks second as the world's largest producer of plastic waste in the ocean after China. Plastic waste dumped in the ocean in 2015 is estimated to reach 187.2 million tons (while in China, it is estimated to reach 262.9 million tons). KLHK stated that plastic waste generated from 100 retail stores or members of the Indonesian Retailers Association (APRINDO) had reached 10.95 million pieces of plastic bag waste within one year. The amount is equivalent to an area of 65.7 hectares of plastic bags or about 60 times the size of a soccer field. The amount of Indonesian waste in 2019 is estimated to reach 68 million tons, and the amount of plastic waste is estimated to reach 9.52 million tons or 14 percent of the total waste.

As a solution to overcome this problem, KLHK targets to reduce plastic waste by more than 1.9 million tons by 2019. The target of reducing waste in 2019 is 25 percent, while 75 percent of waste management technique is carried out by composting and recycling, the remaining waste is taken to the Final Disposal Site (TPA).

A new paradigm in development is to prioritize bottom-up planning to produce maximum participation from the people involved in the development process. The actual development process shall be a socio-cultural change. The development can be a self-sustaining process depending on humans and their social structure. Likewise, to fundamentally resolve the problem of waste management in urban areas, the community shall be empowered optimally. As plastic waste is a major problem in big cities, the community needs to be involved in efforts to manage plastic waste.

The Bogor City Government has officially banned plastic bags at modern retail stores and shopping centers starting from December 1, 2018. The policy to ban the use of plastic bags in modern retail stores and shopping centers is regulated in the Mayoral Regulation No. 61 of 2018 concerning Reducing the Use of Plastic Bags. This policy is expected to reduce plastic waste generated by shopping centers in Bogor City. Based on data from the Environmental Protection Agency of Bogor City, plastic waste generated by shopping centers in Bogor City reaches 1.8 tons per day.

\section{Methodology}

\subsection{Place and Time of Research}

This study was conducted at Minimarket brands in Bogor registered in the Department of Industry and Trade of Bogor City. The minimarkets consist of Indomaret, Alfamart, and YOMART. The researcher selected the minimarkets as research location because the minimarkets are located near the community residence and are easily accessible. In addition, due to the close proximity of community residence, transactions at minimarkets can be frequently carried out, making it easier for sampling.

\subsection{Type and Data Source}

The data used in this study consisted of primary data and secondary data. Primary data was obtained through a questionnaire to research respondents. The questionnaire consisted of open and closed questions. Closed questions are those which can be answered by selecting items from a rating scale. The scale used in this study was the Likert scale with a five-point scale. Secondary data in this study were obtained from the archive of the Industry and Trade Department of Bogor City, journals, theses, and other literature studies.

\subsection{Sampling Method}

The respondent samples in this study were consumers who were met after shopping at the minimarkets. The number of samples taken was 120 respondents. This number was five times the number of manifest variables. According to Ding et al in [2], the minimum sample size ranges from 100-150 when using the covariance structure model. The research location in this study was divided into six locations, namely in West Bogor, South Bogor, Central Bogor, East Bogor, North Bogor, and Tanah Sereal Sub-Districts. Therefore, sampling was performed in each sub-district by a non-probability sampling method, namely quota sampling. Then, a total of 120 respondents were divided into six research locations and it was obtained 20 respondents for each sub-district.

\subsection{Data Processing and Analysis Methods}

Data processing and analysis methods used cross tabulation, descriptive analysis, and structural equation model (SEM). In this study, cross tabulation was used to determine consumer perception of the use of their shopping bags on the characteristics. Descriptive analysis can be seen from the mode value or the value that occurs most often from the respondent's answers and the percentage by a score of the responses. Cross tabulation and descriptive analysis were performed using SPSS 22 software for Windows. Structural equation model (SEM) was used to examine the effect of green marketing of plastic bag reduction policy on green behavior. Testing with SEM was performed using LISREL software.

\section{Result and Discussion}

\subsection{Consumer Response of the Use of Their Own Shopping Bags}

The consumer responses of the use of their shopping bags are presented in Table 1. The data in Table 1 shows that most consumers who are willing to bring their shopping bags are female consumers. The results also show that 42 married consumers are willing to bring their shopping bags. Married consumers usually care about the environment because they expect better 
environmental conditions for their offspring in the future. Therefore, most married consumers prefer to bring their shopping bags.

Table 1. Consumer responses of the use of their own shopping bags

\begin{tabular}{|l|c|c|c|}
\hline \multirow{2}{*}{ Characteristics } & \multicolumn{2}{|c|}{$\begin{array}{c}\text { Perception } \\
\text { (bring their own } \\
\text { shopping bags) }\end{array}$} & \multirow{2}{*}{ Total } \\
\cline { 2 - 3 } & Yes & No & \\
\hline Gender & & & \\
\hline Female & 50 & 48 & 98 \\
\hline Male & 15 & 7 & 22 \\
\hline Total & $\mathbf{6 5}$ & $\mathbf{5 5}$ & $\mathbf{1 2 0}$ \\
\hline Marrital Status & & & \\
\hline Married & 42 & 32 & 74 \\
\hline Single & 23 & 23 & 46 \\
\hline Total & $\mathbf{6 5}$ & $\mathbf{5 5}$ & $\mathbf{1 2 0}$ \\
\hline $\begin{array}{l}\text { Education } \\
\text { Level }\end{array}$ & & & \\
\hline Middle School & 0 & 2 & 2 \\
\hline High School & 15 & 16 & 31 \\
\hline D1 & 1 & 3 & 4 \\
\hline D2 & 2 & 1 & 3 \\
\hline D3 & 15 & 15 & 30 \\
\hline $\begin{array}{l}\text { Bachelor's } \\
\text { Degree }\end{array}$ & 29 & 18 & 47 \\
\hline Master's Degree & 3 & 0 & 3 \\
\hline Total & $\mathbf{6 5}$ & $\mathbf{5 5}$ & $\mathbf{1 2 0}$ \\
\hline
\end{tabular}

Source: Data processed (2019)

Based on Table 1, it can be seen that 29 consumers with an education level of bachelor's degree are willing to bring their shopping bags. One's education level will affect their values, way of thinking, perspective and perception of a problem. Consumers with higher education levels will be very responsive to information [3]. In general, the higher one's education level, the more information obtained and the better the ability to consider logically to determine the choice of needs in consuming a product [4].

\subsection{Consumer Perception of Green Marketing}

Consumer perception of the green marketing process can be seen in Table 2. In this study, the researcher uses five green marketing processes consisting of knowing your customer, empowering customers, reassure the buyer, be transparent and consider your pricing. The five green marketing processes are used as indicators to identify consumer perception of green marketing. Each indicator consists of several statements assessed by the respondents and expressed with a score that matches the perception. Based on Table 2, it can be seen that most respondents agree with the statement of know your customer indicator. The first statement (KYC1) indicates that $60.5 \%$ of respondents have started to reduce the use of plastic bags and the second statement (KYC2) indicates that $62.5 \%$ of respondents have reduced the use of plastic bags after the implementation of a paid plastic bag policy.

Table 2. Consumer perception of green marketing

\begin{tabular}{|c|c|c|c|c|}
\hline Indicator & Code & Question & Mode & $\begin{array}{c}\text { Total } \\
\text { percen } \\
\text { tage }\end{array}$ \\
\hline \multirow{2}{*}{ 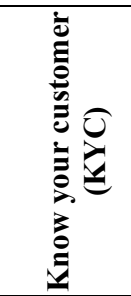 } & $\begin{array}{c}\text { KYC } \\
1\end{array}$ & $\begin{array}{l}\text { Before the implementation } \\
\text { of plastic bag reduction } \\
\text { policy, I have reduced the } \\
\text { use of plastic bags. }\end{array}$ & 4 & $45.4 \%$ \\
\hline & $\begin{array}{c}\mathrm{KYC} \\
2\end{array}$ & $\begin{array}{l}\text { Since the implementation } \\
\text { of plastic bag reduction } \\
\text { policy, I have reduced the } \\
\text { use of plastic bags. }\end{array}$ & 4 & $62.5 \%$ \\
\hline \multirow{2}{*}{ 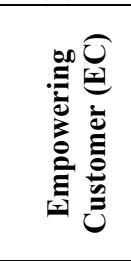 } & EC 1 & $\begin{array}{l}\text { I have knowledge about } \\
\text { the waste problem with the } \\
\text { presence of plastic bag } \\
\text { reduction policy. }\end{array}$ & 4 & $62.5 \%$ \\
\hline & EC 2 & $\begin{array}{l}\text { I usually encourage people } \\
\text { around me to bring their } \\
\text { own shopping bags. }\end{array}$ & 4 & $52.6 \%$ \\
\hline \multirow{2}{*}{ 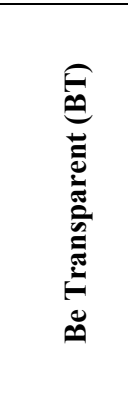 } & BT 1 & $\begin{array}{l}\text { I am very aware about } \\
\text { Bogor Mayoral Regulation } \\
\text { No. } 61 \text { of } 2018 \text { concerning } \\
\text { reducing of the use of } \\
\text { plastic bags officially } \\
\text { issued by the Government } \\
\text { of Bogor City. }\end{array}$ & 4 & $50 \%$ \\
\hline & BT 2 & $\begin{array}{l}\text { I am aware about the } \\
\text { process of making and } \\
\text { drafting plastic } \\
\text { regulation. }\end{array}$ & 3 & $32.9 \%$ \\
\hline \multirow{2}{*}{ 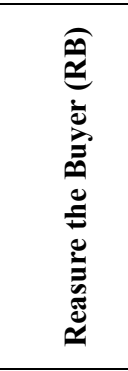 } & RB 1 & $\begin{array}{l}\text { When I shop, the } \\
\text { minimarket staffs usually } \\
\text { informs me that they will } \\
\text { not give plastic bags }\end{array}$ & 4 & $43.4 \%$ \\
\hline & RB 2 & $\begin{array}{l}\text { During transaction at } \\
\text { modern retail stores, the } \\
\text { cashier always offers } \\
\text { environmentally friendly } \\
\text { bags as an alternative of } \\
\text { plastic bags }\end{array}$ & 4 & $37.5 \%$ \\
\hline \multirow{4}{*}{ 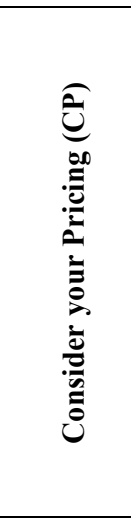 } & CP 1 & $\begin{array}{l}\text { I am willing to pay for } \\
\text { eco-friendly bags as an } \\
\text { alternative of plastic bags }\end{array}$ & 4 & $41.4 \%$ \\
\hline & CP 2 & $\begin{array}{l}\text { In my opinion, plastic } \\
\text { shopping bags should no } \\
\text { longer be provided in } \\
\text { traditional markets }\end{array}$ & 4 & $34.2 \%$ \\
\hline & CP 3 & $\begin{array}{l}\text { In my opinion, the price of } \\
\text { Rp. } 200 \text { for a plastic } \\
\text { shopping bag is costly. }\end{array}$ & 3 & $32.9 \%$ \\
\hline & CP 4 & $\begin{array}{l}\text { In my } \\
\text { Minimarkets should no } \\
\text { longer provide plastic } \\
\text { bags. }\end{array}$ & 4 & $32.2 \%$ \\
\hline
\end{tabular}

Source: Data processed (2019)

These results indicate a change in consumer behavior after the implementation of a plastic bag reduction policy. The result of respondents' assessment of the second statement of be transparent indicator (BT2) indicates that $32.9 \%$ of respondents do not know that the proceeds of the sale of plastic bags are used for 
Corporate Social Responsibility (CSR) activities. This will raise consumer doubts regarding the implementation of plastic bag reduction policy.

\subsection{Consumer Perception of Green Behavior}

The results on Consumer Perception of Green Behavior are presented in Table 3. Based on Table 3, the first statement (GB1) and the second statement (GB2) indicate an increase in consumer awareness to bring their shopping bags while shopping. Before the implementation of plastic bag reduction policy, out of 120 respondents, only $34.9 \%$ of respondents brought their shopping bags while shopping. However, after a plastic bag reduction policy is implemented, the percentage of consumers who bring their shopping bags increases by $17.1 \%$ to $52.0 \%$.

Table 3. Consumer perception of green behavior

\begin{tabular}{|c|c|c|c|c|}
\hline $\begin{array}{l}\text { Indic } \\
\text { ator }\end{array}$ & Code & Statement & Mode & $\begin{array}{c}\text { Total } \\
\text { percen } \\
\text { tage }\end{array}$ \\
\hline \multirow{8}{*}{ 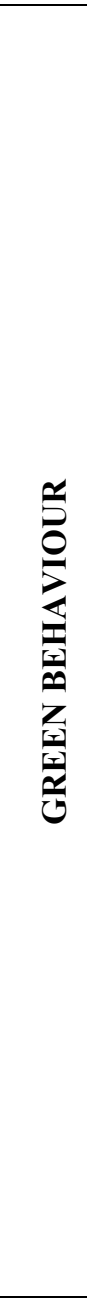 } & GB1 & $\begin{array}{l}\text { Before the } \\
\text { implementation of plastic } \\
\text { bag reduction policy, I } \\
\text { usually bring my own } \\
\text { shopping bag while } \\
\text { shopping. }\end{array}$ & 4 & $34.9 \%$ \\
\hline & GB2 & $\begin{array}{l}\text { Since the implementation } \\
\text { of plastic bag reduction } \\
\text { policy, I usually bring my } \\
\text { own shopping bag while } \\
\text { shopping. }\end{array}$ & 4 & $52.0 \%$ \\
\hline & GB3 & $\begin{array}{l}\text { Currently, I usually try } \\
\text { not to buy foods or drinks } \\
\text { with single-use plastic } \\
\text { packaging. }\end{array}$ & 4 & $48.0 \%$ \\
\hline & GB4 & $\begin{array}{l}\text { I usually segregate } \\
\text { between organic and } \\
\text { inorganic waste before } \\
\text { throwing them into } \\
\text { disposal bin at home }\end{array}$ & 4 & $42.8 \%$ \\
\hline & GB5 & $\begin{array}{l}\text { I usually put waste in its } \\
\text { place. }\end{array}$ & 4 & $35.5 \%$ \\
\hline & GB6 & $\begin{array}{l}\text { I usually collect used } \\
\text { shopping plastic bags for } \\
\text { reuse. }\end{array}$ & 5 & $46.7 \%$ \\
\hline & GB7 & $\begin{array}{l}\text { I really know how to } \\
\text { manage plastic waste in } \\
\text { order to gain benefits. }\end{array}$ & 4 & $38.2 \%$ \\
\hline & GB8 & $\begin{array}{l}\text { I am willing to participate } \\
\text { in protecting the } \\
\text { environment from } \\
\text { pollution. }\end{array}$ & 4 & $52.6 \%$ \\
\hline
\end{tabular}

Source: Data processed (2019)

Table 4. Result of t-value of structural equation model of the effect of green marketing on green behavior

\begin{tabular}{|c|l|c|c|}
\hline No & \multicolumn{1}{|c|}{ Variables } & $\mid$ t-hit $\mid>1.96$ & Conclusion \\
\hline 1 & $\begin{array}{l}\text { Know Your Customer } \\
\text { Green Behavior }\end{array}$ & 8.07 & Significant \\
\hline 2 & $\begin{array}{l}\text { Empowering } \\
\text { Customer Green } \\
\text { Behavior }\end{array}$ & 5.12 & Significant \\
\hline 3 & $\begin{array}{l}\text { Reassure the Buyer } \\
\text { Green Behavior }\end{array}$ & 5.04 & Significant \\
\hline 4 & $\begin{array}{l}\text { Be Transparent Green } \\
\text { Behavior }\end{array}$ & 1.63 & Insignificant \\
\hline 5 & $\begin{array}{l}\text { Consider Your } \\
\text { Pricing } \\
\text { Behavior Green }\end{array}$ & -1.85 & Insignificant \\
\hline
\end{tabular}

Source: Data processed (2019)

\subsection{Analysis Results of Effect of Green Marketing of Plastic Bag Reduction Policy on Green Behavior Using Structural Equation Model}

The results using structural equation model indicated that green marketing process which had a significant effect on green behavior was know your customer, empowering customer and reassure the buyer. Table 4 shows the result of t-value indicating a significant effect of green marketing on green behavior. 4.5 Interpretation of the Effect of Green Marketing of Plastic Bag Reduction Policy, Environmental Attitude and Environmental Knowledge on Green Behaviour

Standarized solution or standarized loading factor is used as a basis for interpreting the results of parameter estimates model [5]. Fig. 1 shows the results of structural model of standarized loading factor. Based on the test results shown in Table 3 and Fig. 1, it can be concluded that green marketing factor which has the greatest effect is know your customer with a value of 0.46 . Know your customer means that in making policy, the government shall have knowledge on the extent of the level of public awareness about the environment. The results indicate that if the government's knowledge of the consumer conditions is higher, then the policy affecting changes in community's behavior in the use of plastic shopping bags will increase green behavior.

Another green marketing process which has a direct and significant effect on green behavior is empowering customer and reassure the buyer. The government needs to figure out how the plastic bag reduction policy can be well received and firmly embedded in the minds of consumers. As a regulator making a plastic bag reduction policy, the government's efforts have been sufficient in formulating and convincing consumers on the policy implementation. 


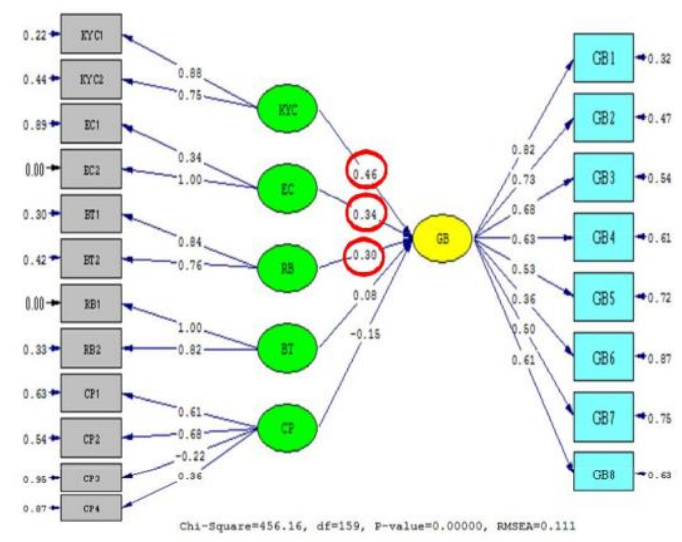

Fig. 1. Path diagram of standardized loading factor testing of the effect of green marketing on green behavior

Description: $\longrightarrow=$ Variables affecting green behavior

The green marketing process which does not affect green behavior is transparent and consider your pricing. The government shall implement a transparent and clear policy. The legal basis for implementing policy shall be well-founded and the funds generated from the sale of paid plastic bags shall be clearly used. Based on the results, $50 \%$ of respondents are unaware of the implementation of the plastic bag reduction policy based on the Bogor Mayoral Regulation Number 61 of 2018 concerning reducing the use of plastic bags.

The results of this study also indicate that $32.9 \%$ of consumers are not aware of the process of drafting regulation for reducing plastic bags. The government should provide a more detailed explanation of the mechanism for implementing important policies so that the community will be confident that the policy will run according to its function. Eventually, the community is willing to participate in the implementation of policy and the policy objectives can be achieved as expected.

Marketing activities are not only intended for products in the form of goods or services, but the government policy also requires good marketing so that the objectives of implementing the policy can be achieved in accordance with the government expectation. Plastic bag reduction policy is one issued by the Bogor City Government.

Plastic bag reduction policy can be implemented effectively by considering the green marketing process, especially know your customer, empowering the customer and reassure the buyer. In addition, the characteristics of consumers as the policy target, consumer responses to the use of their shopping bags and consumer opinions on the implementation of plastic bag reduction policy need to be considered.

Based on the results of this study on consumer perception of green marketing on know your customer indicator, it can be determined that the number of respondents who begins reducing plastic bag use increases by $17.1 \%$. This change indicates the success of the plastic bag reduction policy in changing consumer behavior. Therefore, know your customer indicator can be classified as a driving force to support the changes.

The solution to overcome the lack of public knowledge about the policy mechanism is to provide socialization to the community. Clearer information will increase public confidence so that the community will not hesitate to participate in implementing the policy. The government can provide socialization by providing information through public service advertisements on television, social media, and the internet. Television, social media, and the internet are sources of information that are easily accessible and closer to the community so that they are more desirable.

The implementation of a plastic bag reduction policy is expected to provide knowledge and increase public awareness about the importance of environmental protection. Thus, people's behavior to be more environmentally friendly and wiser to use plastic bags can be improved by conducting socialization about the harms of plastic waste and its impact on the environment. The Regional Government can also hold activities for the community to support the plastic waste reduction program, for example, by holding a plastic free day once a month or once a week.

\section{Research Limitation and Future Research Agenda}

In this study, the research location was limited to the modern retail stores in the minimarket scale. Further studies are suggested to be conducted with a broader scope. The research location can be conducted at supermarkets with larger samples in order to obtain deeper analysis results.

\section{Conclusion}

Based on the results of this study, it can be concluded as follows: most of the consumers who were willing to use their shopping bags when shopping were female consumers, married consumers and consumers with an education level of bachelor's degree. Most respondents agree with the statements about green marketing factors and green behavior. After the policy was implemented, more consumers have reduced the use of plastic bags. However, some consumers did not know that the funds generated from the sale of plastic bags were used for CSR activities. The green marketing process which had a positive and significant effect on green behavior was to know your customer, empowering the customer and reassure the buyer.

\section{References}

1. J.R. Jambeck, R.Geyer, C. Wilcoc, T.R. Siegler, M. Perryman, A. Andrady, R. narayan, K.L Law, Plastic Waste Inputs from Land into the Ocean (2015) 
2. I. Ghozali, Structural Equation Modeling Teori, Konsep dan Aplikasi dengan LISREL 8.54, Badan Penerbit Universitas Diponegoro (2005)

3. U. Sumarwan, Consumer Behavior: Theory and Practice in Marketing, Bogor, Indonesia: PT Ghalia Indonesia (2004)

4. Syahbandi, JEBIK 3(1) (2012)

5. Kusnendi, Model-Model Persamaan Struktural. Satu dan Multigroup Sample dengan Lisrel (2008) 